\title{
Metics, members and citizens
}

\author{
Will Kymlicka and Sue Donaldson
}

Rainer Bauböck’s essay argues persuasively that our account of democratic inclusion needs to be more complex than is usually recognized. Whereas most authors attempt to identify a single fundamental principle of democratic inclusion - whether it is the all affected interests principle or the all subjected to coercion principle or some social membership/ stakeholder principle - Bauböck shows that there are different types of polities with different principles of inclusion, and that the appropriate principles for inclusion at one level depend in part on the principles operative at other levels. Birthright citizenship at the national level, for example, makes possible both residency-based citizenship at the local level and derivative or nested citizenship at the federal level, just as the latter two modes of citizenship help to correct potential injustices or forms of domination generated by birthright citizenship at the national level.

We are in broad agreement with Bauböck's general story about the need to complicate theories of democratic inclusion by recognizing multiple principles of democratic inclusion tied to multiple types of polity. The aim of this commentary is to push his project one step further, by adding another layer of complexity to our thinking about democratic inclusion. We will focus on a range of cases that fall outside our normal assumptions about who is eligible for, or capable of, citizenship, including children, people with cognitive disabilities and domesticated animals.

What members of these groups have in common is that they are members of society, in a sociological sense - living out their lives as part of a transgenerational "core" community, engaging in intersubjective 
communication, participating in cooperative activity, abiding by social norms - but they lack the capacity to engage in the kind of rational deliberation about political propositions that is widely assumed to characterize democratic citizenship. As Gary Steiner (2013) notes, most theories of citizenship have assumed that citizens have what he calls "linguistic agency" - the ability to articulate, understand, evaluate, negotiate and commit to abstract linguistic propositions regarding the terms of social cooperation with their fellow citizens. ${ }^{1}$ But in reality, many members of society are not linguistic agents. Where do they fit in our theory of citizenship?

Bauböck does not say much about such groups, and what little he says, we will argue, is inadequate. In this respect, he follows much of the Western political tradition, which has systematically ignored the rights and status of social members who are not capable of deliberative political speech. We will argue that these cases raise a fundamental challenge to our theories of democratic inclusion, not just about who is included, but also about what it means to be a citizen and how to characterize the underlying moral purposes of citizenship.

To foreshadow, our argument is that these cases reveal a deep tension within democratic theory between two models of citizenship: what we call a "membership model", which defines citizenship in terms of social membership; and a "capacity contract", which defines citizenship in terms of capacities for particular kinds of political agency. ${ }^{2}$ The former entails that children, people with cognitive disabilities and (we will argue) domesticated animals count as citizens; the latter entails they do not. Most theorists appeal to both, and then seek to square the circle by

\footnotetext{
We realize that "linguistic agency" can be defined more expansively, in ways that would recognize many animals as linguistic agents. As discussed below, members of these groups are certainly communicative. We are using the phrase "linguistic agency" to isolate the capacity shared by many humans, and no non-human animals of which we are aware, for engaging in a process of discursive reason-giving about abstract propositions.

2 We take the phrase "capacity contract" from Clifford (2014). The contract language is misleading if it suggests a voluntary agreement. It is used here, rather, in the same sense that theorists talk of "the racial contract" (Mills 1997), "the sexual contract" (Pateman 1988) or the "settler contract" (Nichols 2013): as a deeply embedded social logic that structures our institutions and practices in hierarchical terms.
} 
creating various subordinate forms of membership-without-citizenship. Bauböck's argument can be seen as a version of this strategy.

We will argue that there is no way to square the circle: the two models are simply contradictory, requiring us to choose between them. ${ }^{3}$ We will also argue that, confronted with that choice, liberals should simply abandon the capacity contract. This would not, by itself, require rejecting the basic structure of Bauböck's model, with its three distinctive principles for the three distinctive forms of polity. Indeed, it would strengthen it, by providing a clearer and more defensible account of both the circumstances and purposes of citizenship.

\section{The membership model}

Current debates in political philosophy on democratic inclusion arose initially in response to the problem of what Michael Walzer called "metics" - the existence of large numbers of immigrants who had settled long term in European countries, such as the Turkish Gastarbeiter in Germany, yet who were not eligible for citizenship. Indeed, even their children, born and raised in the country, were sometimes ineligible for citizenship (Walzer 1983). Walzer argued compellingly that this was an injustice. These long-time residents were clearly members of society, not just in the sense that they paid taxes and obeyed the law, but in the deeper sense that they had made a life in their new society and formed a dense web of social ties. In the case of their children, this was often the only home they knew. Yet they were treated as aliens and outsiders. Walzer argued this was both unjust and undemocratic.

This initiated a search within political philosophy to specify more precisely the principle that grounds a right to citizenship for metics. For many theorists, the first reaction was to appeal to some version of the all affected interests principle: metics are entitled to citizenship because

\footnotetext{
Toby Rollo suggests that the tension between the capacity contract and the membership
} model is one of the most "intractable problems in political theory" (Rollo 2016: n.p.). 
their interests are affected by the decisions of the state in which they live. But on sober second thought, it became clear that this principle is problematic. The set of individuals who are affected by political decisions varies from issue to issue in ways that make it impossible to develop a stable demos. For example, while all of our decisions are likely to affect some foreigners, the set of foreigners affected by an environmental policy is likely to be different from a trade policy - just as these policies affect some but not all residents within the country - leading to ever-changing boundaries of inclusion on a case-by-case basis. In Bauböck's words, "letting affected interests determine the boundaries of the demos would create indeterminate or ephemeral demoi that are structurally incapable of ruling themselves" (p. 11). ${ }^{4}$

Whether the all affected interests principle can be salvaged from this criticism is an ongoing debate in the literature (e.g. Goodin 2007; List and Koenig-Archibugi 2010; Saunders 2011; Koenig-Archibugi 2012; Song 2012). But in any event, it is clearly a misdiagnosis of the original problem of the metics. In fact, it arguably replicates that injustice, by putting metics on a par with foreigners, as prima facie outsiders who might nonetheless qualify for inclusion on particular decisions because they have affected interests. The Turks in Germany are not just saying that they are affected by this or that public policy of the German government, but that they are members of the public in whose name the state governs. They are part of German society - they belong there and have made a life there. It is the failure to recognize this fact of social membership that creates the injustice - not the failure to take into account some discrete interest affected by a particular German policy. If Germany adopts an industrial policy that has spillover pollution costs for people in Poland or Denmark, that is a harm to affected interests for which

Moreover, taken to its logical conclusion, the all affected principle seems to entail a single global demos. After all, my interests are affected, not just when choosing between two options, but also when those options themselves are selected to be the focus of choice: what Bauböck calls the "agenda-setting" power (p. 22). And if we have a right to be part of the demos whenever agenda-setting powers might affect us, we quickly reach the idea of a single global demos - see Goodin (2007). 
some sort of accountability and remedy is required. ${ }^{5}$ But permanently relegating a portion of German society to the status of non-citizen metics is a very different type of injustice, for which a different remedy is required. The all affected interests principle has nothing useful to say about addressing this type of injustice.

In response to this defect of the all affected interests principle, other theorists have proposed the "all subject to coercion" principle as a basis for grounding rights to citizenship for metics. This seems closer to the mark, since it focuses not just on incidental or unintended impacts on interests of discrete policies, but on a more direct relation of governing. The Turkish metics are not just affected by German policies, but are governed by them. But this too doesn't quite capture the injustice of the metics' situation. After all, even short-term tourists or visitors are subject to the law, and so would seem to qualify for rights of inclusion under the all subject to coercion principle. ${ }^{6}$ Yet the whole point of the metics example is that it is wrong for the German government to treat them as if they were visitors or tourists, rather than as full members of society. It is no response to this problem to say that even if they are just visitors, they still have democratic rights. That leaves untouched the fundamental injustice of being treated as an alien or outsider in the society where one has made one's life. Insofar as tourists are subject to coercion they may well have rights to equal protection of the law and to contest the arbitrary exercise of power, but that is different from the right of members of society to inclusion in the demos.

The case of the metics shows that citizenship is not ultimately about being affected by particular decisions or being subject to particular laws, but about membership in a self-governing society. People living in foreign societies are affected by our decisions, and tourists visiting our society are subjected to our laws, and these facts are politically consequential - we

See Bauböck pp. 25-26 for helpful suggestions about the appropriate remedy for these external impacts.

6 And on the other hand, it seems to provide a pretext for colonization of other societies, so long as one then grants citizenship to the colonized. 
need to be held accountable for these impacts and these exercises of power. But citizenship is about being a member of a self-governing society. In short, citizenship should track social membership. ${ }^{7}$

We can call this the membership model of citizenship, which ties citizenship to an ethos of membership. To be a citizen is to be a member of the society (or "the public" or "the people") in whose name the state governs, and one central function of citizenship is precisely to acknowledge this membership, to acknowledge who belongs here, who has made a life here, and who therefore has a right to shape the terms of our shared social life.

Many passages in Bauböck's text can be seen as endorsing this membership model. He says that we are "social animals" (p. 40) who have a stake in membership as such which is different from a stake in the protection of a particular policy interest or a particular legal right. Because of the kind of social animals we are, we thrive as members of an intergenerational community, bound together by ideas of belonging to, and ownership of, a bounded society. We are not a "merely functional aggregates of individuals who happen to share an interest in a particular political decision" (p. 11). Rather, we make a life for ourselves in a particular society, develop social ties within that society, and our well-being is pervasively tied up with the shared norms that govern the scheme of social cooperation, and with how we are treated by our fellow members. Citizenship is an acknowledgement of this "stake in membership": it affirms that we are members of this intergenerational community, and that, as such, we have a right to shape its social norms and to co-author its laws, as well as a responsibility for its long-term future. ${ }^{8}$

The locus classicus for this social membership model is Carens $(2005,2013)$.

Some commentators argue that this picture of the importance of membership in bounded societies is increasingly obsolete in an age of mobility, but we share Bauböck's view that individual mobility is possible and valuable because it takes place on a terrain structured by the operation of bounded societies with a "relatively sedentary core population" (p. 17). In this sense, the enduring importance of social membership is one of the "circumstances of democracy" (pp. 7-18). 
As we said, many passages in Bauböck's text can be read as supporting this membership model, which we take to be the most compelling account of democratic inclusion. However, in other places he backs off this view, and suggests that social membership is not a sufficient condition for political membership. In various places, ${ }^{9}$ he implicitly suggests that belonging to the "public" or the "demos" is qualitatively different from belonging to "society" or "community", and suggests that one's interest in being recognized as a member of society is not sufficient for being recognized as a citizen. The net result, as we will see, is that he condones creating a new set of metics. Most of the original metics - such as the Turkish Gastarbeiter - may be included as citizens on his account, but a whole new set of members of society are rendered ineligible for citizenship. These passages are puzzling, and at odds with the liberal and democratic impulses that otherwise inform his account. We will return to these passages below, but let us first spell out the broader implications of the social membership model.

\section{Inclusive membership ${ }^{10}$}

While the migrant workers in northern Europe were the initial case that stimulated recent work on democratic inclusion, a moment's reflection would reveal that they are not the only group that is relegated to the status of metics within contemporary democracies. There are many other groups that are clearly members of society but who are denied the rights of democratic citizenship. Consider children, who form around one-third of the population of any given society. Or consider people with cognitive disabilities, who number in the millions in some countries. ${ }^{11}$ They are clearly members of society. They are born into a

Including in his commentary on Joseph Carens in Bauböck (2015).

10 The following section draws on ideas we have developed in other work (e.g. Donaldson and Kymlicka 2016a).

11 And with ageing populations, living longer lives, the number of people with various forms of dementia will increase. 
society, participate in its social relationships, share in the benefits and burdens of social cooperation, and live their lives within its territorial boundaries. And this fact of social membership is acknowledged in nationality law: children and people with cognitive disabilities typically have the formal status of citizenship or nationality by birth. They are not foreigners or stateless. Yet these members of society are denied substantive citizenship, and are disenfranchised (universally in the case of children, to varying degrees in the case of people with cognitive disabilities). As members of society, they are typically accorded certain rights to protection (against harm) and provision (of public services), but they are denied the rights to participate in democratic shared rule which defines modern accounts of citizenship. ${ }^{12}$ (This denial of political rights has come under increasing scrutiny, and is directly challenged by the UN Convention on the Rights of Persons with Disabilities.)

An even more striking case concerns domesticated animals. They too are members of society, at least according to most standard sociological definitions of sociality (i.e. intersubjective recognition, communication, trust, cooperation, compliance with shared norms). Domesticated animals share a social world with us, and play a vital role in our schemes of economic production and social cooperation, a reality which is now widely acknowledged (and studied) by sociologists and anthropologists (Peggs 2012). They too live and die within our societies, and they too belong here. Having been taken out of the wild and bred over centuries to be dependent on us, they have no other home. In that sense, domesticated animals are, sociologically speaking, members of our societies, whose fate is entirely tied up with how they are treated under our social norms and institutions. They would therefore seem to qualify for citizenship under a membership model that ties citizenship to being a member of

Commentators often talk about a "3P" model of citizenship rights - protection, provision and participation - which should apply to all members of society (see, for example, Quennerstedt 2010). In reality, most children and people with cognitive disabilities are at best accorded a $2 \mathrm{P}$ model, without participation rights. And since domesticated animals have the status of property in law, they are denied all three, lacking legal recognition of personhood or membership even in the thinnest sense. 
society. ${ }^{13}$ Yet, virtually without exception, theorists of citizenship have excluded animals, often in the very same sentence that they exclude children and people with cognitive disabilities, ${ }^{14}$ relegating them to the status of metics.

One might think that this exclusion is inevitable because members of these groups simply are unable to engage in some of the core practices of citizenship, such as jury duty, voting or public political deliberation. But from a membership perspective, this gets things backwards. We don't start with some received view about essential citizenship practices and then ask who qualifies for citizenship in virtue of being able to perform these practices. Rather, we start from some account of who is a member of society - in Bauböck's terms, who has a "stake in membership" - and then ask how to organize politics to enable all members to enact their citizenship. If not every member of society is able to vote or to engage in public reason, then we need to find alternative ways of enabling those members to have a say in the governing of society.

In fact, important work has already been done in imagining how to extend democratic citizenship to children (Moosa-Mitha 2005; Rehfeld 2011; Bacon and Frankel 2014), and to people with cognitive disabilities (Francis and Silvers 2007; Arneil 2009; Clifford 2014; Davy 2015). These experiments in democratic inclusion have emerged, partly in response to the mobilization of advocates, but also in response to recent changes in international human rights law, which emphasize that both children and people with cognitive disabilities have a right to a say in matters that affect them - that is to say, rights to participation, and not just rights to protection and provision. ${ }^{15}$

13 For a detailed defence of this argument, see Donaldson and Kymlicka (2011: chs 4 and 5) and Kymlicka and Donaldson (2014).

14 Among many such examples, see Hobbes: "Over natural fools, children, or madmen there is no law, no more than over brute beasts; nor are they capable of the title of just or unjust, because they had never power to make any covenant or to understand the consequences thereof" (Leviathan II.xxvi.12).

15 See note 12 above for the $2 \mathrm{P}$ versus $3 \mathrm{P}$ model of citizenship. 
Implementing this right to a say is obviously a major social and political challenge, but the basic idea should not be particularly mysterious. After all, children and people with cognitive disabilities are clearly wilful individuals, with strong preferences about the sorts of activities and relationships in which they would like to engage. They are also quite communicative about these preferences. They may not communicate through reasoned propositions, but they have a host of other communicative strategies for expressing their preferences and negotiating relationships (e.g. utterances, body language, demonstrative actions). And they are capable of forming trusting relationships with others who can create the social conditions under which alternative activities and relationships can be safely explored. An individual's subjective response to these alternatives can then be observed and analysed, and those subjective responses can in turn be incorporated into collective decision-making. There is nothing particularly mysterious about any of this, all of which takes place on a daily basis, and various societies have explored how to connect these everyday potentialities for communication and voice into the broader political process - that is, how to enable democratic citizenship. As Hartley notes of people with cognitive disability, while they may lack the capacity for linguistic agency, they certainly have what she calls the "capacity for engagement" (Hartley 2009), and wherever this exists, possibilities for democratic engagement exist.

And once we accept this possibility in the case of children and people with cognitive disabilities, there is no conceptual obstacle to applying it to domesticated animals as well (Meijer 2013; Donaldson and Kymlicka 2016a). All of the facts that make democratic citizenship possible for young children and people with cognitive disabilities - facts about individual wilfulness, communication, trust, engagement, dependent agency and the structuring of choice situations - are also at play in our relations with domesticated animals. (Indeed, animals could not have been domesticated had they lacked these capacities for interspecies sociability.)

In any event, this is the logic of the membership model: we start with an account of who is a member of society, and we ask how to 
enable all members of society to participate in shaping the shared norms that govern our life together. This is a vision of a truly democratic society, one in which democratic values animate the governing of social life.

\section{The capacity contract}

Unfortunately, Bauböck does not follow this logic. On his story, membership in the demos is not a right of social membership, but a privilege restricted to those who possess certain sophisticated cognitive capacities for rational deliberation. Indeed, on a more careful read, his argument that as "social animals" we have a "stake in membership" in "transgenerational human societies" turns out to have little to do with social membership in the sense described above (i.e. making a life for oneself within a particular society, developing social ties within that society, complying with social norms, participating in schemes of social cooperation that determine the distribution of burdens and benefits). Rather, his argument isolates a much more specific interest of certain people - namely, linguistic agents - in being members of a specifically political association that is defined by certain deliberative practices. Only people who are able to participate in these deliberative practices qualify for membership in the demos.

The result is that, on Bauböck's model, a gulf emerges between those who are merely members of society, and those who are members of the demos who govern society. In the case of children and people with cognitive disabilities, he says that we can still use the honorific "citizens" to describe them, in the sense that they are co-nationals with a right to belong. But he then insists that citizenship in this sense is not a right to democratic inclusion: not all "citizens" are members of the demos with rights to participate or to co-author the shared norms of society (p. 46). Only linguistic agents are members of the demos - that is, only they are entitled to democratic citizenship. Others have some sort of shadowy pseudo-citizenship - that is, something other 
than the kind of democratic citizenship that tracks membership in the demos. ${ }^{16}$

In this respect, Bauböck implicitly endorses what Stacy Clifford calls a "capacity contract", by which some members of society are deemed to be naturally governed by others (Clifford 2014). According to the capacity contract (democratic) citizenship should be limited to those who are by nature capable of ruling, while all others are relegated to some subaltern status, such as semi-citizenship (Cohen 2009) or wardship (or, in the case of animals, property).

This capacity contract runs very deep in the Western political theory tradition, dating back at least to Aristotle, who famously explained that man is a "political animal" because of his "gift of speech":

Now that man is more of a political animal than bees or other gregarious animals is evident. Nature, as we say, makes nothing in vain, and man is the only animal who she has endowed with the gift of speech. And whereas mere voice is but an indication of pleasure or pain, and is therefore found in other animals (for their nature attains to the perception of pleasure and pain and the intimation of them to one another, and no further), the power of speech is intended to set forth the expedient and inexpedient, and therefore likewise the just and unjust. And it is a characteristic of man that he alone has any sense of good and evil, of just and unjust, and the like, and the association of living beings who have this sense makes a family and a state. ${ }^{17}$

16 For a similar manoeuvre of defining democratic citizenship in terms of the capacity for linguistic agency but then granting honorific citizenship to others, see Hinchcliffe (2015). Bauböck's decision to extend the honorific "citizen" to children and people with cognitive disabilities, even though he denies they are members of the demos, muddies the conceptual clarity of his argument. Having introduced this distinction half-way through the text, one would need to go back through his entire text and ask, each time that the word "citizen" appears, whether he is referring to "mere" citizenship without rights to participation, or to the full democratic citizenship that entails membership in the demos, or to both. We leave this as an exercise for the reader, but we think several passages trade on the ambiguity.

17 Aristotle, Politics, in Hutchins (1987: 446). On the foundational significance of this view for the Western philosophical tradition, see Franklin (2011), Steiner (2013) and Wadiwel (2015). 
For Aristotle, only those with "the power of speech" to "set forth the just and unjust" can be party to a political relationship or members of a political community. Humans who lack this power, like other animals, may have "the perception of pleasure and pain", but they are incapable of articulating and deliberating their interests and claims in abstract propositional form and are therefore disqualified from being "political" animals.

This idea is so embedded in our philosophical tradition and political imagination that we have trouble thinking outside of it. There is growing acceptance that domesticated animals share a social world with us, just as we have no hesitation in accepting that children and people with cognitive disabilities share social membership with us. But as Gwendolyn Blue and Melanie Rock note, we seem incapable of accepting that they can be part of the public:

Developments in social theory over the past few decades have unsettled deeply entrenched assumptions about what constitutes the human by exposing the tenuous divisions that separate humans, non-human animals and technologies and, in turn, affording a more active role to non-human entities in the constitution of social worlds. The concept of the public, however, remains persistently, stubbornly, and somewhat curiously entrenched in anthropomorphic imaginaries. Within and outside of academe, it is commonplace to suppose that publics are purely human and that publics arise from the unique human capacity for symbolic communication. (Blue and Rock 2014: 504)

Noortje Marres and Javier Lezaun make a similar observation about our inability to understand politics outside of linguistic agency:

The idea that language is the central vehicle of politics - that language, in fact, founds and sustains the difference between human politics and the lives and quarrels of those (beasts or gods) who exist outside the polity - is so deeply ingrained in our preconceptions of the political that it is almost impossible to imagine a public, particularly a democratic one, not constituted primarily by acts of discursive deliberation. We have only 
to think of a term such as "public sphere", and the careful delimitation of the kinds of activities conducive to its emergence that defines its use in contemporary democratic theory, to grasp the difficulty of coming up with a political vocabulary that is not premised on disembodied "voice" and linguistic exchange. (Marres and Lezaun 2011: 492)18

And we should note that virtually every single textbook in political philosophy published in the past thirty years implicitly or explicitly endorses the capacity contract, and the restriction of the public to linguistic agents. ${ }^{19}$

Given this enduring legacy, it is hardly surprising that Bauböck ends up recapitulating the central terms of the capacity contract. But in our view it remains puzzling, and at odds with the spirit of inclusion that otherwise informs his work. It resolves one case of metic exclusion but in the process creates another one, and indeed an even larger one.

It is not easy to discern what precisely is Bauböck's argument for denying that all members of society should be members of the demos. In places, he suggests that what distinguishes the demos as a political association from the rest of social life is the activity of "self-government". Self-government is the purpose of political association, and only rationally deliberating linguistic agents have a stake in the activity of self-government. But talk of self-government cannot justify the capacity contract. After all, the linguistic agents whom Bauböck empowers to rule society are not just governing themselves. He is not proposing that linguistic agents form a club that would govern its members according to their own rules about deliberation, in the way that a chess club might

18 We should note that while we endorse these calls to conceive "more-than-human" publics, we do not endorse the "new materialist" or "actor network theory" approach which elides the distinction between wilful agents and non-sentient life forms (e.g. Latour 2005; Bennett 2009). Our remarks here are restricted to non-human animals. And while many non-human animals have affected interests that need to be taken into account, we believe that it is primarily domesticated animals with whom humans share the "circumstances of democracy", including the fundamental facts of sociability and capacity for engagement.

19 See Donaldson and Kymlicka (2016b) for a more systematic review.

20 Also in Bauböck (2015). 
govern itself. Rather, he is saying that linguistic agents have the right to exercise state power, and thereby govern society. The power of the state, which on a social membership model belongs to all members of society, becomes the property of the subset of linguistic agents. ${ }^{21}$ In this sense, the capacity contract does not grant a right of self-government to linguistic agents, but something quite different - it grants a right to rule over others. (The right to rule over others is in fact at the heart of the capacity contract.) It is difficult to see how this can be justified in terms of a right to self-government.

So what, then, explains this "persistent" and "stubborn" clinging to the capacity contract? There are undoubtedly several factors, which we discuss elsewhere (Donaldson and Kymlicka forthcoming). But it is worth noting that the historical origins for the capacity contract are fundamentally illiberal and undemocratic. For Aristotle, the function of politics was to display a series of gender, class, racial and species supremacies: politics was where men revealed themselves to be superior to women, the propertied revealed themselves to be superior to slaves, the Greeks revealed themselves to be superior to barbarians, adults revealed themselves to be superior to children, and humans revealed themselves to be superior to animals. This affirmation of hierarchy, and exclusion of the inferior, was the point and purpose of politics: politics was where we display our exalted status. For Aristotle and his latter-day acolytes, mere members of society are just the backdrop or the stage on which exalted agents exercise their unique (male, propertied, Greek, human) powers. Medieval and Renaissance philosophers maintained this perfectionist preoccupation, although they tied it to Christian doctrines about humanity's distinctive place in divine creation: organizing politics around rational speech appropriately marked our favoured position as made in God's image, above other animals.

${ }^{21}$ Bauböck says that "it is the larger transgenerational society that collectively governs itself and not the subcategory of adults who have the capacity ... to vote or hold public office" (p. 46). But in fact he provides no account of how anyone outside that subcategory can take part in collectively governing society, and on the contrary he explicitly states that only this subcategory forms the demos. Here again, the conceptual argument is muddied by the equivocation between mere citizens and democratic citizens. 
Needless to say, there is nothing liberal or democratic in any of this, and most contemporary political theorists officially disavow this Aristotelian legacy. For contemporary theorists, the function of politics is not to express species essences or divine providence, but to ensure that the distribution of the benefits and burdens of social cooperation is just, and to ensure that the exercise of political power over the governed is legitimate. But if so, then it is very difficult to understand why we should maintain the capacity contract, rather than rejecting it as a deeply illiberal inheritance. Both justice and legitimacy would seem to push us in the direction of the membership model of citizenship. Children, people with cognitive disabilities and domesticated animals may not engage in the forms of rational speech that Aristotle and Aquinas viewed as definitively human, but they clearly comply with social norms and carry the burdens of social cooperation, and they are clearly subject to the exercise of political power. They therefore have a stake in shaping our social norms, and if our concern is with justice and legitimacy rather than with exalting species essences, these facts of social participation and political subjection should be sufficient to warrant rights to participate. As we discussed earlier, this is in fact the direction that real-world reforms are taking, as new models of how to enable the engagement of children, people with cognitive disabilities and domesticated animals are continually being explored.

On Bauböck's model, by contrast, our duty to support and enable the political participation of our fellow members of society depends on whether they fall above or below some stipulated threshold of cognitive or linguistic competence. For those who fall above, we have strong duties not just to permit the exercise of their linguistic agency, but also to support it, including translation services or Braille or hearing aids, as well as rights to information and access. But if they fall below this threshold, then it appears we have no obligation to make any effort to solicit their subjective good or to be responsive to it when making collective decisions. Above the threshold, they are active citizens with strong claims to public support for their democratic agency; below the threshold, they are passive wards with no claims on public support for their democratic agency. 
It is difficult to see any justification for this differential treatment. ${ }^{22}$ The linguistic and cognitive capacities of society's members vary across multiple dimensions, all of which are continua. In our view, a truly democratic society would seek to support the political agency of all its members, wherever they fall on these continua, rather than finding ad hoc or arbitrary thresholds to empower some and exclude others.

The capacity contract is not only arbitrary, but also generates politically pernicious myths and prejudices. Since every long-term member of society who complies with social norms and bears the burdens of social contribution would seem to have a prima facie claim to democratic citizenship, defenders of the capacity contract are prone to trivialize the contributions, burdens and the extent of their political subjection of the excluded. In order to justify excluding children, people with cognitive disabilities and domesticated animals from democratic citizenship, there is pressure to hide the unpleasant truth about the caste and metic status of these members of our society. Some theorists claim that children and people with cognitive disabilities inhabit a "separate but equal", or even a privileged, status. Theirs is allegedly an honoured and protected status of social membership, freed from the burdens and responsibilities of democratic citizenship. This is reminiscent of old anti-suffragist arguments about how much women (allegedly) stood to lose by coming down off their (supposed) pedestals to be recognized as grubby democratic citizens. In all of these cases, the commitment

22 This arbitrary differential treatment reveals the fallacy in Bauböck's claim that we need to keep animals out of citizenship in order to preserve a commitment to equality ("challenging this [human-animal] political boundary ... might do great harm to the idea of equality of membership that is fundamental to democracy", p. 47). This not only ignores the reality that there are already plural and group-differentiated forms of membership, but it also ignores the fact that it is a commitment to the capacity contract that ruptures the idea of equality of membership. The capacity contract preserves the appearance of equality of membership by expelling all members who do not fit a pre-ordained vision of citizenship that was defined by and for some subset of members. As we have seen, it preserves an image of equality in self-government by granting rights to govern over others. This is not self-government by equal citizens: it gives some the right to rule over themselves and others. This is a Procrustean victory for equality. 
to exclude or segregate certain members from citizenship generates cognitive pressure to redescribe their exclusion as a beneficial form of pastoral care and protection, ignoring the realities of burdens, harms and subjugation.

We can see this peeking through in Bauböck's text, where he says that "there is nothing degrading about treating children as children" ( $\mathrm{p}$. 46). But we would argue that "treating children as children" is degrading if it means subjecting them to arbitrary power, or trivializing their responsibilities, their work and their contributions, as is widespread in our society (Such and Walker 2005; Lister 2007). ${ }^{23}$ Moreover, membership in transgenerational political communities is very much part of the "animal condition", despite Bauböck's assertion otherwise (p. 47). Domesticated animals are almost certainly more subject to political regulation than humans: where they can live or move, what they can eat, whether they can reproduce, and when and how they are killed, are all minutely regulated by the state (Smith 2012).

That defenders of the capacity contract systematically obscure the realities of power, burden and contribution should not be surprising, since these are the bases of claims to citizenship on the membership model. Since the membership model says that individuals are owed citizenship in virtue of enduring participation in schemes of social cooperation that are subject to collective governance, defenders of the capacity contract are more or less compelled to deny or trivialize the extent to which children, people with cognitive disabilities and domesticated animals are subject to power or engage in contribution.

23 Bauböck acknowledges that "treating children as children" may include "responsibilities to allow them to participate in all decisions concerning them" (p. 46). But, as we noted earlier, he provides no account of how anyone other than neurotypical adults can take part in collectively governing society (see note 21 above). In any event, his apparent exception for children rests on the logic that we owe them participation not in virtue of what they are - not in virtue of their interests or membership as children - but in virtue of what they will become (adult citizens). This privileging of children's "becoming" over their "being" is precisely the idea that children's rights advocates rail against, since it accords no recognition of the importance of the quality of a child's life as such, in their childhood years (see Arneil 2002). And if we accept that children are owed participation because of their being, not just their becoming, then we have no grounds to exclude animals. 
We can't review here all of the intellectual hoops and gymnastics that defenders of the capacity contract undertake to justify their position, ${ }^{24}$ but we would suggest the time has come for political theorists to simply abandon the capacity contract. Given the stubborn persistence of the capacity contract, and the cultural and intellectual barriers standing in the way of dismantling it, we are not surprised by its appearance in Bauböck's essay. And we welcome the fact that, unlike most political theorists, he at least flags the issue as one that needs to be acknowledged. More importantly, we believe that Bauböck's work in articulating multiple principles of democratic inclusion tied to multiple types of polity could prove extremely fruitful for thinking about the democratic challenges facing more-than-human political communities. Different kinds of human and animal communities inhabit overlapping territories in complex ways, without necessarily forming shared societies. For example, many non-domesticated animals have interests that are affected by our decisions while not being subject to human governance to any significant degree, let alone being part of a shared demos. Some animals living in remote wilderness areas, for example, are not subject to coercion, but may be affected by human activity such as pollution, climate change or aircraft flight paths. We have duties to take their affected interests into account, but not to include them in the shared demos. Other non-domesticated animals, by contrast, are subject to extreme state violence and coercion. Consider the rodents, pigeons, foxes and countless others who are poisoned, spiked, gassed, shot and ripped apart according to the laws of the human community. As Bauböck notes, justice demands that those subject to the coercive force of the law must share equal protection of the law - and we would argue this should apply to urban wildlife - but

24 Of course, one obvious explanation for its persistence is that political theorists have a pre-theoretical commitment to excluding non-human animals from the demos, in order to continue to enjoy the "flow of pleasures" that is generated by their caste status (Wadiwel 2015), and simply work backwards to find theoretical premises that will generate this result, regardless of the tensions and contradictions this creates for their theories. Whether animals are to be included or excluded is not something to be resolved by appeal to independently justified political principles: rather, we select political principles on the basis of whether they will keep animals out. 
here again, being subject to the law does not automatically translate into membership in the demos. Domesticated animals, on the other hand, are genuinely members of our society, and so have a genuine stake in membership in a mixed human-animal political community (as we argued above).

In short, once divorced from the capacity contract, Bauböck's distinctions between "all affected interests", "all subject to coercion" and "all citizen stakeholders" can help us to better understand the diverse patterns of human-animal political relations. Furthermore, Bauböck's concept of nested polities can help us address some of the challenges raised by the fact that humans and non-human animals share spaces and territories in ways which do not neatly line up with the nature, extent or density of governance and social relationships. He may or may not approve, but we will certainly make use of Bauböck's nuanced theory of the complex matrix of polities and democratic principles in order to push forward a new model of democracy that includes all members of society, in all their profuse diversity.

\section{References}

Aristotle. 1987. Politics. In The Works of Aristotle: Volume 2, edited by Robert Hutchins. Chicago: Encyclopaedia Britannica.

Arneil, Barbara. 2002. "Becoming Versus Being: A Critical Analysis of the Child in Liberal Theory." In The Moral and Political Status of Children, edited by David Archard and Colin M. Macleod. Oxford: Oxford University Press: 70-96. Arneil, Barbara. 2009. "Disability, Self Image, and Modern Political Theory." Political Theory 37 (2): 218-242.

Bacon, Kate and Sam Frankel. 2014. "Rethinking Children's Citizenship: Negotiating Structure, Shaping Meanings." International Journal of Children's Rights 22: 21-42.

Bauböck, Rainer. 2015. "From Moral Intuition to Political Change: On Joseph Carens' Theory of Social Membership and Open Borders." Political Theory 43: 393-401. 
Bennett, Jane. 2009. Vibrant Matter: A Political Ecology of Things. Durham: Duke University Press.

Blue, Gwendolyn and Melanie Rock. 2014. "Animal Publics: Accounting for Heterogeneity in Political Life." Society and Animals 22: 503-519.

Carens, Joseph. 2005. “The Integration of Immigrants." Journal of Moral Philosophy 2 (1): 29-46.

Carens, Joseph. 2013. The Ethics of Immigration. Oxford: Oxford University Press. Clifford, Stacy. 2014. “The Capacity Contract: Locke, Disability, and the Political Exclusion of 'Idiots"' Politics, Groups, and Identities 2 (1): 90-103.

Cohen, Elizabeth. 2009. Semi-citizenship in Democratic Politics. Cambridge: Cambridge University Press.

Davy, Laura. 2015. "Philosophical Inclusive Design: Intellectual Disability and the Limits of Individual Autonomy in Moral and Political Theory." Hypatia 30 (1): $132-148$.

Donaldson, Sue and Will Kymlicka. 2011. Zoopolis: A Political Theory of Animal Rights. Oxford: Oxford University Press.

Donaldson, Sue and Will Kymlicka. 2016a. "Rethinking Membership and Participation in an Inclusive Democracy: Cognitive Disability, Children, Animals." In Disability and Political Theory, edited by Barbara Arneil and Nancy Hirschmann. Cambridge: Cambridge University Press: 168-197.

Donaldson, Sue and Will Kymlicka. 2016b. "Locating Animals in Political Philosophy." Philosophy Compass 11 (11): 692-701.

Donaldson, Sue and Will Kymlicka. Forthcoming. "Expanding the Boundaries of Citizenship." In Oxford Handbook of Citizenship, edited by Ayelet Shachar, Irene Bloemraad, Maarten Vink and Rainer Bauböck. Oxford: Oxford University Press.

Francis, Leslie and Anita Silvers. 2007. "Liberalism and Individually Scripted Ideas of the Good: Meeting the Challenge of Dependent Agency." Social Theory and Practice 33 (2): 311-334.

Franklin, Julian. 2011. "Animal Rights and Political Theory." In Oxford Handbook of the History of Political Philosophy, edited by George Klosko. Oxford: Oxford University Press: 756-769.

Goodin, Robert. 2007. "Enfranchising All Affected Interests, and Its Alternatives." Philosophy and Public Affairs 35 (1): 40-68. 
Hartley, Christine. 2009. "Justice for the Disabled: A Contractualist Approach." Journal of Social Philosophy 40: 17-36.

Hinchcliffe, Christopher. 2015. "Animals and the Limits of Citizenship: Zoopolis and the Concept of Citizenship." Journal of Political Philosophy 23 (3): 302-320.

Hobbes, Thomas. 2010. Leviathan. Revised Edition, edited by A.P. Martinich and Brian Battiste. Peterborough: Broadview Press.

Koenig-Archibugi, Mathias. 2012. "Fuzzy Citizenship in Global Society." Journal of Political Philosophy 20 (4): 456-480.

Kymlicka, Will and Sue Donaldson. 2014. "Animals and the Frontiers of Citizenship." Oxford Journal of Legal Studies 34 (2): 200-219.

Latour, Bruno. 2005. Reassembling the Social: An Introduction to Actor-NetworkTheory. Oxford: Oxford University Press.

List, Christian and Mathias Koenig-Archibugi. 2010. "Can There Be a Global Demos? An Agency-Based Approach.” Philosophy and Public Affairs 38 (1): $76-110$.

Lister, Ruth. 2007. "Why Citizenship: Where, When and How Children?" Theoretical Inquiries in Law 8 (2): 693-718.

Marres, Noortje and Javier Lezaun. 2011. "Materials and Devices of the Public: An Introduction." Economy and Society 40 (4): 489-509.

Meijer, Eva. 2013. "Political Communication with Animals." Humanimalia 5 (1): $28-52$.

Mills, Charles. 1997. The Racial Contract. Ithaca: Cornell University Press.

Moosa-Mitha, Mehmoona. 2005. "A Difference-Centred Alternative to Theorization of Children's Citizenship Rights." Citizenship Studies 9 (4): 369-388.

Nichols, Robert. 2013. "Indigeneity and the Settler Contract Today." Philosophy and Social Criticism 39 (2): 165-186.

Pateman, Carole. 1988. The Sexual Contract. Cambridge: Polity.

Peggs, Kay. 2012. Animals and Sociology. London: Palgrave.

Rehfeld, Andrew. 2011. “The Child as Democratic Citizen.” Annals of the American Academy of Political and Social Science 633: 141-166.

Rollo, Toby. 2016. "Feral Children: Settler Colonialism, Progress, and the Figure of the Child." Settler Colonial Studies. Published online 29 June 2016, http:// dx.doi.org/10.1080/2201473X.2016.1199826, accessed 25 May 2017. 
Quennerstedt, Ann. 2010. “Children, But Not Really Humans? Critical Reflections on the Hampering Effect of the '3Ps"', International Journal of Children's Rights 18 (4): 619-635.

Saunders, Ben. 2011. "Defining the Demos." Politics, Philosophy and Economics 11 (3): 280-301.

Smith, Kim. 2012. Governing Animals: Animal Welfare and the Liberal State. Oxford: Oxford University Press.

Song, Sarah. 2012. "The Boundary Problem in Democratic Theory: Why the Demos should be Bounded by the State." International Theory 4 (1): 39-68.

Steiner, Gary. 2013. Animals and the Limits of Postmodernism. New York: Columbia University Press.

Such, Elizabeth and Robert Walker. 2005. "Young Citizens or Policy Objects? Children in the 'Rights and Responsibilities' Debate." Journal of Social Policy 34 (1): 39-57.

Wadiwel, Dinesh. 2015. The War Against Animals. Amsterdam: Rodopi. Walzer, Michael. 1983. Spheres of Justice: A Defense of Pluralism and Equality. New York: Basic Books. 